\title{
Małgorzata Pietrasiak
}

\section{ROSJA WOBEC AZJI}

Robert Jakimowicz, Geostrategiczny wybór Rosji u zarania trzeciego tysiaclecia, t. 3: Polityka Federacji Rosyjskiej wobec regionu Azji i Pacyfiku, Azji Centralnej i Arktyki, Wydawnictwo Uniwersytetu Jagiellońskiego, Kraków 2015, ss. 367.

Monografia zatytułowana Polityka Federacji Rosyjskiej wobec regionu Azji i Pacyfiku, Azji Centralnej i Arktyki jest trzecim tomem książki Geostrategiczny wybór Rosji u zarania trzeciego tysiąclecia, będącej rezultatem badań finansowanych przez Narodowe Centrum Nauki. Cała „trylogia” analizuje różne kierunki i aspekty polityczne, gospodarcze, jak też militarne oraz podstawy ideologiczne aktywności Federacji Rosyjskiej na arenie międzynarodowej. Recenzowany tom dotyczy regionu Azji i Pacyfiku, Azji Centralnej i Arktyki. Autor książki, prof. Robert Jakimowicz, jest specjalistą w tym zakresie, a jego dorobek stanowi dobrą rekomendację, aby i tę monografię potraktować z należytym zainteresowaniem.

Książka składa się z sześciu rozdziałów, z których każdy jest poświęcony innemu obszarowi geograficznemu. Autor wyjaśnia cele badawcze i tezy, jak również najważniejsze pojęcia i metodologię we wstępie, książka zawiera również obszerną bibliografię, spis tabel i map. Położenie Rosji i jej aspiracje powrotu do pozycji z okresu zimnowojennego powodują, że aktualne staje się pytanie, czy Rosji uda się taki mocarstwowy status osiągnąć. Dylemat, który z kierunków - proeuropejski i prozachodni czy też azjatycki - należy traktować priorytetowo, zawsze był obecny w polityce rosyjskiej. Zwrot ku Azji, po części wymuszony zmianą nastawienia UE do Rosji, a po części będący naturalnym zainteresowaniem wszystkich mocarstw rozwijającą się Azją Wschodnią, jest widoczny zwłaszcza w okresie prezydentury Władimira Putina. We wstępie autor krótko określa, jak różnorodne na- 
rzędzia Rosja stosuje, zwraca również uwagę, że korzystanie z narzędzi miękkich w przypadku Rosji jest niewystarczające w stosunku do narzędzi twardych, i podaje przykład Japonii, wobec której ze względu na toczący się spór terytorialny sięganie do środków z grupy soft jest niezadowalające. Szkoda, że Jakimowicz tej tezy związanej ze zróżnicowaniem stosowanych metod i środków polityki zagranicznej nie konkretyzuje. Takie porównanie byłoby potrzebne w kontekście efektywności realizacji celów polityki zagranicznej.

Zdecydowanie słusznie wybrzmiała postawiona teza, że zaniedbany rosyjski Daleki Wschód staje się „dodatkiem handlowym” rozpędzonych gospodarczo Chin. Przy względnie stałych warunkach geopolitycznych Chiny mogą się stać tym drugim obok Stanów Zjednoczonych biegunem współczesnego świata.

Rozdział pierwszy, Chiny jako najważniejszy partner azjatycki Federacji Rosyjskiej w regionie Azji i Pacyfiku, jest rozdziałem wprowadzającym. Podkreślone są tu zależności, problemy we wzajemnych relacjach i sposób ich rozwiązania, wspólne i rozbieżne interesy na arenie międzynarodowej. Autor wymienia te sytuacje oraz szczegółowo je omawia.

$\mathrm{W}$ tym rozdziale przeanalizowane są również relacje gospodarcze. $\mathrm{Z}$ całą pewnością mimo wysiłków władz centralnych i wzajemnych deklaracji te rozwijają się wolno i nie zadowalają strony rosyjskiej. Autor opisuje różne podejścia chińskich ekspertów, naukowców i polityków do współpracy z Rosją, przytacza ich diagnozę jej złej sytuacji gospodarczej. Wyraźnie widać, że te diagnozy nie są jednolite.

Dalej Jakimowicz omawia stosunki gospodarcze, w tym również problematykę paradyplomacji rosyjskiego Dalekiego Wschodu oraz współpracy międzyregionalnej. Według niego to, że Chiny traktują ten obszar jako surowcowe zaplecze, to również wina Rosji. Do tej pory nie zadziałały programy gospodarcze ukierunkowane na jego rozwój, co jest widoczne właśnie w zacofaniu gospodarczym. Determinantą stosunków chińsko-rosyjskich jest czynnik amerykański. Autor pisze o tym na stronie 83, choć wywód zabrzmiał dość niezrozumiale: „Bez utrzymywania więzi ze Stanami Zjednoczonymi niemożliwy jest znaczący wzrost i rozwój gospodarki i polityki, a stosunki Chin ze Stanami Zjednoczonymi dlatego są priorytetowe, ponieważ USA mogą blokować osiągnięcie chińskich celów strategicznych w polityce wewnętrznej i zewnętrznej”.

Następnie autor omawia relacje w sferze militarnej, a na końcu narzędzia soft. Tutaj ogranicza się do współpracy uczelni, a szkoda, ponieważ strony poszukują nowych możliwości kontaktów, organizowane są liczne festiwale i konkursy, a w Rosji działają liczne Instytuty Konfucjusza.

Rozdział drugi zatytułowany Wielowymiarowe znaczenie Azji Centralnej poświęcony jest polityce Rosji wobec tego obszaru. Jakimowicz rozpoczyna go od omówienia historii politycznej po upadku ZSRR, prób usamodzielnienia się państw 
powstałych w jego wyniku, relacji z Rosją, problemów z tożsamością. Wymiar militarny to głównie Szanghajska Organizacja Współpracy i porozumienia dwustronne. Opis powiązań gospodarczych i wzajemnych problemów jest bardzo solidny. Autor kończy rozważania na czasach współczesnych.

Rozdział trzeci poświęcony jest stosunkom z Japonią. Szeroko opisane jest tło historyczne, poczynając od przełomu XVIII i XIX w. Nie jestem jednak przekonana, że ten dość długi wstęp historyczny w strukturze pracy jest potrzebny. Następnie autor omawia okres ZSRR, kwestie polityczne i geostrategiczne, próby politycznych kompromisów i zawarcia traktatu pokojowego, a także wizyty oficjalne. Część gospodarcza stosunków, podobnie jak poprzednie, przedstawiona jest bardzo starannie. Warto zwrócić uwagę, że wszystkie rozdziały podporządkowane są określonemu schematowi wypowiedzi, co ułatwia czytelnikowi śledzenie i porównywanie polityki Rosji wobec państw i regionów Azji.

Czwarty rozdział dotyczy współpracy z Koreą, zarówno Południową, jak i Północną. Również w tym wypadku zastosowany został ten sam schemat narracji: stosunki polityczne, potem gospodarcze $\mathrm{i}$ inne.

Rozdział piąty poświęcony jest nowemu kierunkowi polityki zagranicznej, czyli Arktyce. Rozpoczyna się od opisu Arktyki i jej znaczenia międzynarodowego. Następnie wymienione są państwa konkurujące o Arktykę: Stany Zjednoczone, Kanada, Norwegia i Dania. Dodatkowo autor opisał interesy chińskie, japońskie i koreańskie wobec Arktyki.

Rozdział szósty dotyczy obecności Rosji w regionie Azji i Pacyfiku. Elementem rozważań są stosunki z Wietnamem jako członkiem ASEAN. Wydaje mi się, że to zagadnienie należałoby potraktować szerzej, relacje te bowiem są wielowątkowe, nacechowane zaszłościami historycznymi, ważne dla obu stron. Rosja nie jest jednak jedynym państwem, z którym Wietnam ustanowił partnerstwo strategiczne. Do jego strategicznych partnerów należą Indie, Wietnam jest koordynatorem współpracy tego państwa z ASEAN, a oprócz tego jego partnerami strategicznymi są Japonia i Chiny. W tym rozdziale autor omawia również aktywność Rosji w APEC.

Podsumowując, praca jest bardzo starannie napisana, zgromadzono i wykorzystano w niej obszerny materiał badawczy. W sposób rzeczowy i obiektywny przeanalizowano politykę Rosji wobec poszczególnych obszarów. Polecam książkę jako inspirację do dalszych przemyśleń naukowych, podręcznik akademicki dla studentów nauk politycznych i stosunków międzynarodowych oraz dla tych wszystkich, którzy zajmują się współczesną Rosją. 